\title{
Sentrale temas in die prediking van Desmond Tutu
}

H J C Pieterse

\section{ABSTRACT}

Crucial themes in the preaching of Desmond Tutu.

A sample of Tutu's published sermons, a few speeches and a statement were analysed by means of content analysis in a qualitative empirical approach. My co-researchers were professor Peer Scheepers (Sociology), doctor Fred Wester (Methodology) and professor J A van der Ven (Practical Theology) - all of Nijmegen University in the Netherlands. In this article I answer questions such as: Which crucial themes Tutu adressed in his preaching? How did he rhetorically used these themes in order to convey his message? What is the theological basis of his prophetic preaching? What was the communicative approach in his preaching? The results will surely be a surprise to many people. The research shows that his sermons are rhetorically sound, his communication dialogical and his theology built on the concept of salvation (Jesus' victory over evil through his death and resurrection).

\section{INLEIDNG}

Alhoewel Aartsbiskop Desmond Tutu 'n omstrede persoon was vir baie Afrikaanssprekendes, het die meeste mense tog besef dat sy boodskap effektief is. Vir my as homileet was sy prediking van die begin af merkwaardig. Daarom het ek ses jaar gelede besluit om 'n wetenskaplike analise van 'n steekproef van sy preke, enkele toesprake en verklarings te maak. Ek het die samewerking van enkele kollegas in Nederland verkry en die resultate van die ondersoek is pas gepubliseer ${ }^{1}$.

Die ondersoekvrae wat in hierdie artikel bespreek word, is die volgende:

a) Watter sentrale temas kom in Tutu se prediking voor?

b) Hoe het hy hierdie temas argumentatief ingespan om sy boodskap oor te dra?

c) Wat is die teologiese basis van sy profetiese prediking?

d) Met watter kommunikasiebenadering werk hy? 
Die navorsingsontwerp is 'n plan of 'n sistematiese prosedure waarvolgens die ondersoek gedoen word'.

\subsection{Steekproef}

By wyse van 'n teoretiese steekproef ${ }^{3}$, wat deur Glaser en Strauss ${ }^{4}$ in kwalitatiewe navorsing gebruik word, is 'n aantal preke, enkele toesprake en verklarings van gepubliseerde tekste van Tutu geselekteer om te verseker dat dit 'n variasie verteenwoordig oor 'n tydperk met verskillende gehore en situasies waarin daar gekommunikeer is. Op hierdie wyse is twaalf tekste versamel wat strek oor 'n periode vanaf 1977 tot 1992. Die gehore wissel van slegs swart en slegs wit tot rasgemende gehore. Die meeste preke en toesprake is in vreedsame situasies gelewer, maar 'n aantal is ook by onstuimige gehore, waar geweld die aanleiding tot die geleentheid was, gelewer 5 .

\subsection{Metode van inhoudsanalise}

Die mees sinvolle wyse om tekste empiries te ondersoek met die oog op die beantwoording van die ondersoekvrae wat in hierdie artikel gestel is, en die groot aantal vrae in die groter ondersoek ${ }^{6}$, is ' $n$ inhoudsanalise met 'n kwalitatiewe benadering?.

Een van die medewerkers aan hierdie Tutu-ondersoek, Fred Wester, het saam met ander metodoloë 'n rekenaarprogram ontwikkel (Kwalitan) wat in kwalitatiewe ondersoek gebruik kan word8, en dit vir die inhoudsanalise aangepas?.

'n Meetinstrument met sleutelwoorde (temas en subtemas) is uit die teorie van die Suid-Afrikaanse bevrydingsteologie en die konteks van apartheid, asook uit die twaalf tekste ontwikkel wat elke stukkie inhoud met ' $n$ sleutelwoord dek ${ }^{10}$. Dit is op rekenaar met die Kwalitanprogram geplaas. Met die druk van 'n sleutelwoord kry 'n mens dus elke deeltjie van die inhoud daaronder op jou skerm. Die analises kon dus makliker en presieser gedoen word as die ouer metodes van inhoudsanalise.

\subsection{Teologiese refleksie}

Nadat die empiriese analises gedoen is, kon ons die teologiese refleksie op die materiaal doen. Dit moet beklemtoon word dat hierdie 'n empiriesteologiese studie is - dit is dus van die begin af met teologiese teorieë 
aangepak. Die teologiese refleksie op die materiaal is gedoen aan die hand van die teorieë van die bevrydingsteologie, teologiese kommunikasieteorieë soos dit in die homiletiek gebruik word en die klassieke teologiese teorie oor die betekenis van Jesus se kruisdood.

\section{SENTRALE TEMAS}

Wat teologiese temas betref, het Tutu in die tekste wat ons ondersoek het 187 keer (30\%) bevrydingsteologiese temas gebruik en 105 keer (17\%) algemene teologiese temas.

Wat die politieke temas aanbetref, het hy temas wat die politieke realiteit ontbloot en skets 179 keer $(29 \%)$ aan die orde gestel en temas oor die politieke toekoms 25 keer (4\%).

Die belangrikste teologiese tema in die tekste is dat God aan die kant van die onderdruktes is (75 keer, dit is $12 \%$ ). Die tweede hooftema in hierdie verband staan in verhouding tot die eerste, naamlik dat God beslis bevryding en vryheid vir die onderdruktes sal bewerkstellig ( $29 \mathrm{keer}$, dit is 5\%). Omdat Jesus deur sy kruisdood en opstanding mense verlos, sal Hy ook in die Suid-Afrikaanse situasie sowel die onderdruktes as die onderdrukkers bevry, want God is 'n God wat versoening bring (23 keer, dit is $4 \%$ ). Daarom moet apartheid afgetakel word (22 keer, dit is $4 \%$ ). Hierdie verandering moet egter vreedsaam en sonder geweld geskied (8 keer, dit is $1 \%$ ). Nege en twintig keer (5\%) word na Christelike waardes verwys waarin liefde tot die naaste die belangrikste is op grond van Jesus se soenverdienste aan die kruis. Hy verwys verder 37 keer (6\%) na Bybelse temas waarvan die kruisdood en die opstanding van Jesus 'n sentrale rol speel.

Wat die politieke temas aanbetref, het Tutu die beskrywing van die politieke realiteit (179 keer, dit is $29 \%$ ) aan die orde gestel met die konsekwensies daarvan vir die mense van Suid-Afrika (42 keer, dit is 7\%). Die opsies vir politieke verandering is 36 keer $(6 \%)$ en die politieke toekoms 25 keer (4\%) in die tekste ter sprake gebring. Na die historiese agtergronde vir die apartheidsisteem is 21 keer $(3 \%)$ verwys.

Dit is egter belangrik om na te gaan hoe hy die temas argumentatief ingespan het in sy retoriese aanpak.

\section{DIE ARGUMENTASIESTRUKTUUR VAN DIE TEKSTE}

Ons het by elke teks 'n opsomming van die temas gemaak wat daarin voorkom. Dit het ons gehelp om die argumentasiestruktuur van elke teks 
op te stel12. Hierdie argumentasiestruktuur le die wyse bloot waarop hy sy boodskap oorgedra het deur sy temas op 'n spesifieke manier in te span.

'n Ondersoek van die argumentasiestruktuur het ons gelei tot 'n algemene konklusie oor sy boodskap. Dit lui soos volg: "The Christian faith as interpreted in liberation theology is stronger than the politics of apartheid"13.

Dit blyk uit die wyse waarop hy sy temas ingespan het dat hy 'n algemene patroon het waarin die negatiewe van die politieke situasie telkens positief gedraai word deur 'n teologiese tema daarteenoor te stel. 'n Goeie voorbeeld hiervan is die argumentasiestruktuur van sy preek by die dood van Steve Biko (1977):

"a. A political theme, the background of Biko's death, is changed from negative (loss) to positive by relating it to a general theological theme, Jesus' death and resurrection and to themes from liberation theology: liberation and freedom.

b. A political theme, the Black Consciousness Movement, is made positive by connecting it with themes from liberation theology: peace and humanity.

c. A political theme, the System (of apartheid), is made negative by connecting it to a theological theme: the powers of evil.

d. A political theme, the System (of apartheid), is changed from negative to neutral by equalizing it with a theological theme, the evil, that has been defeated by the liberator God, a liberation-theological theme" 14 .

Wat ook uit die analises blyk, is dat die politieke temas meestal as agtergrond (konteks) dien vir sy aktuele verkondiging van die toekomstige oorwinning oor die kwaad van apartheid deur God, die Bevryder, op grond van Jesus se oorwinning oor die kwaad (evil) aan die kruis.

\section{TEOLOGIESE AKSENTE}

Uiteraard speel die temas van die bevrydingsteologie 'n groot rol in die tekste wat ons ondersoek het (kyk 3 hierbo). Tutu het ook 'n eie aksent in die Suid-Afrikanse bevrydingsteologie, wat ek graag 'n profetiese teologie noem ${ }^{15}$. Hierdie profetiese teologie vorm die onderbou van sy profetiese prediking.

Dit is interessant dat hy op 'n paar punte ander aksente le as die gangbare bevrydingsteologie in Suid-Afrika. Dit word soos volg in ons boek saamgevat: 
"The first is that in liberation theology, reconciliation is preconditioned by justice as by dismantling apartheid. This would imply chronologically: first justice in society by dismantling apartheid, then reconciliation between oppressors and oppressed. Conversely, Tutu has proposed a more unconditional reconciliation. He reaches out symbolically to the whites to confess their guilt and then they will be forgiven in order to build together with all other South Africans a new, just and more equal society to which all will have to contribute their share.

The second is that in liberation theology, negotiations are preconditioned by the unbanning of liberation movements, the release of all political prisoners and the repatriation of all the exiles. Conversely, Tutu has proposed more unconditional negotiations. It seems that he prefers parties to come to the negotiation table first to start the process instead of formulating preconditions that may hamper the start of the process as such.

Third, civil disobedience has been emphasized in liberation theology both as a strategy and as a principle to combat apartheid and bring about a liberated society. But, conversely, Tutu has not strongly adopted nor encouraged this principle. Instead, he has appealed to the masses to stay calm, to stay disciplined, not to lose their temper, not to provoke the police authorities, etc. It seems that he has warned the masses for the risks of civil disobedience, i.e. the risks of escalation of violence followed by risks of large-scale injuries or eventually killings" 16 .

Alhoewel die tema van die uittog uit Egipte voorkom in sy prediking, vorm dit nie in die eerste plek die teologiese basis waarop hy sy profetiese prediking bou nie. Die teologiese basis is die oorwinning van Jesus Christus aan die kruis op Golgota oor die bose. Sy kruisdood en opstanding is die grond vir die geloof en hoop dat die bose sisteem van apartheid in die stof sal byt en God bevryding vir al die mense van ons land, swart en wit tesame, sal bring. Die heil ('salvation') is die basiese teologiese konsep vir sy profetiese oortuiging dat apartheid oorwin sal word17. Trouens, in sy toespraak by die Universiteit van Pretoria in 1981 het hy hierdie konsep duidelik die voorrang gegee:

"In this same speech he made a profound statement, namely that liberation is not seen as an alternative to salvation. Salvation (the deed of salvation by Jesus' victory over evil) is therefore the basic theological concept which functions in the texts we analysed"18. 
Die homiletiek het in die sestigerjare van hierdie eeu 'n groot weerstand begin ontwikkel teenoor die eensydige dogmatiese benadering in die vak onder die invloed van Karl Barth. Die diskrepansie tussen die dogmatiese aansprake van wat die preek is, en die praktyk van die verkondiging, het al duideliker geblyk. Daar het 'n krisis in die denke oor die preek ontstaan wat opgelos moes word ${ }^{19}$.

Praktiese teoloë soos H-D Bastian, E Lange en K-W Dahm het die wending na die kommunikatiewe benadering in die homiletiek geïnisieer. Werke soos dié van Zerfass ${ }^{20}$, en hier te lande dié van Pieterse ${ }^{21}$, het hierdie benadering in die homiletiek vrugbaar gemaak, terwyl Henau22 een van die pioniers in die Nederlandse taalgebied was.

As Henau na dertig jaar 'n balans opmaak oor die verworwenhede wat hierdie benadering in die homiletiek gebring het, noem hy - naas die besef dat die hoorders selektief luister, dat die preek as noodsaaklike vorm van kommunikasie onvervangbaar is, dat beeldende taal 'n sine qua non is - ook die insig dat die preek nie liniêr en asimmetries (outoritêr) kommunikeer nie, maar op 'n simmetriese vlak binne die konsep van herrschaftsfreie Kommunikation van Habermas moet geskied23. Dit skakel ook in by die Bybelse gees van dialogiese kommunikasie en die kommunikasiepraxis van Jesus ${ }^{24}$.

In die analise van die tekste van Tutu het die vraag dus ontstaan of hy ' $n$ aanvoeling vir hierdie soort kommunikasie in die prediking het. Dit was te meer 'n dringende vraag omdat die studie van Burbach2s uitgewys het dat die politieke prediking in Wes-Duitsland oor die periode 1968-1987 (toe die opkoms van die kommunikatiewe benadering vol in bloei gestaan het) in 'n outoritêre kommunikasiestyl geskied het.

Die dialogiese kommunikasieteorie wat deur Pieterse ontwikkel is, is in die Tutu-ondersoek verder verfyn en gekonseptualiseer. Dit is as ideëeltipe teenoor die outoritêre as ideëeltipiese teenhanger gekonseptualiseer $^{26}$. Die begrippe in die teorie is in vyf hoofkategorieë gesistematiseer:

a Siening van die ander/deelgenoot in die kommunikasie.

b Kommunikasiesituasie.

c Doel van die kommunikasie.

d Vorm van die kommunikasie.

e Inhoud van die kommunikasie. 
Onder elke hoofkategorie is vier konsepte (van die dialogiese teorie) omskryf en teenoor vier van die outoritêre as teenhangers gestel. Daar is geen ruimte in 'n artikel om hierdie uitgebreide teorie nog 'n keer weer te gee nie. Daarom volstaan ek met die konsepte in die eerste hoofkategorie as voorbeeld van hoe dit gedoen is. 'n Volledige omskrywing van elke konsep word in die boek gegee ${ }^{27}$. Hier kan dit nie gedoen word nie daarom dek die voorbeeld ook slegs konsepte van een hoofkategorie.

Hoofkategorie (a) word as voorbeeld geneem. Dit heet 'Siening van die ander/deelgenoot in die kommunikasie'. Hierdie hoofkategorie handel oor die antropologiese benadering in 'n dialogiese kommunikasieteorie binne 'n christelik-teologiese konteks. Om reg te laat geskied aan die formulering van die saak word dit hier in die Engels uit die boek aangehaal - weer eens - as 'n voorbeeld van hoe te werk gegaan is, ook in die ander vier hoofkategorieë. Die eerste deel is ' $n$ inleidende paragraaf28:

"Humankind was created by God. This biblically based religious statement indicates the basic human relatedness to God. Christians are seen as children of God, their Father, and as brothers and sisters to each other in the faith. A human being is created a unique person, an ' $I$ ', with freedom and the ability to take decisions, thus determining his or her own destiny. Consequently each person is a fully resposible creature, accountable for her or his own choices. Human beings are created in the image of God and are therefore responsible for the creation as God's representatives on earth; are oriented towards God and destined to fellowship with God and with one another. We are always involved in relationships - with God, with one another and with nature - and this gives meaning to our lives. In order to actualise ourselves, people need relationships conducive to dialogue, mutual understanding and fellowship. Because the individual is involved in so many complex relationships we must adopt a total or holistic view of humankind. They are not just spiritual or just biological beings - we must see them holistically. Human life is fraught with pain, suffering, imperfection, conflict, oppression and violence. Nevertheless Christians live in hope, the most hopeful message being the gospel of liberation in Jesus Christ. Through faith in Christ both the individual and society can be mobilized to restore the human condition in harmony with the recreation in Christ. The recreated faithful person finds a new humanity, wrought in the image of Jesus Christ. 
The first dimension of main category (a) is:

'Gives meaning to message and acts thereupon'.

The authoritarian opposite is:

'Behaviour a product of factors playing on its organization'.

Symbolic interactionism sees the human being as a being that engages in social interaction with itself by making indications to itself and responding to such indications. The human being is seen as an organism that has to deal with what it notes. It makes an object of what it notes, gives it meaning, and uses the meaning as the basis for directing its action. Although we hear the sounds of behaviourism here symbolic interactionism, in a critical mode against behaviourism, formulates well the human competency to give meaning to messages. Therefore - and here we hear the sounds of the dialogical approach in communication bedded in the hermeneutic tradition - it is open to dialogue and a process of understanding in order to come to an understanding with other people.

In the coventional view the human being is seen as a responding organism, with its behaviour being a product of the factors playing on its organization or an expression of the interplay of the parts of the organization. This 'conventional' view is behaviouristic, from which symbolic interactionism inhereted much. The conventional view sees a human being therefore as a person that merely responds to the play of factors on it. Authoritarian preaching works with this view of human beings.

The second dimension is 'defending the other against humiliation and destruction' with its authoritarian contrast 'seeing the other as potential convert to own idea'.

A dialogical theory of communication, based on the broad paradigm of Habermas' theory of communicative acts, views historical processes from the perspective of its victims. Therefore one takes the position of solidarity with the suffering, the poor and the oppressed. An unrestricted communicative community with all its victims of domination must be created. Communication in this approach will be sensitive to humiliation and destruction. The communication exactly takes place in order to defend the victims against further humiliation and leads them to liberation. 
Authoritarian communication has no eye for the effect on the lives of people as a result of its communication in the sense of domination and humiliation. It only sees the other as a potential convert to its own idea that is usually regarded as the real truth.

The third dimension is 'active participant' with its contrast 'receiver'.

In Kierkegaard's view the individual has to make personal existential decisions and live authentically on her or his own responsibility. This is possible through communication with God and other people. Kierkegaard regarded himself as a dialectician, believing that communication should be real dialogue between two or more free, independant subjects. Communicator and recipient are therefore on equal terms. The recipient is the turning point in becoming the communicator (in his turn) in the exchange of messages and ideas in a spiral of ongoing dialogue, in stead of being the receiver, the end destination of the communication. There is an interactive process going on in the mind of the individual and with others in a dialogical communication.

In authoritarian communication the receiver is seen as the end of the destination of the communication.

The fourth dimension (in this first main category) is 'co-believer' with its contrast 'not sharing the correct views'.

In the dialogical approach the communication partner/church member is seen as 'one of us', as a brother or sister, even if he/she does not share the views of the preacher. In this sphere of freedom and openness communication is a dialogical process that moves in the direction of mutual understanding.

People with different views from the preacher are in an authoritarian approach seen as opposition to the truth held by the church/preacher/in-group. If they refuse to accept the message of the preacher they run the risk of being regarded as "not one of us'".

Die tekste van Tutu in die ondersoek is deur Fred Wester en $\mathbf{H ~ J ~ C ~}$ Pieterse geanaliseer aan die hand van die dimensies van die teorie soos dit 
vooraf uitgespel is in sy dialogiese en outoritêre teenpole ${ }^{29}$. Die bevinding was dat die dialogiese kommunikasiestyl in die preke en toespreke onrheers - selfs in die meer lesingtipe kommunikasies. Dit staan in 'n interessante kontras met Burbach se bevinding oor die outoritêre kommunikasiestyl van die Wes-Duitse politieke prediking.

\section{SLOT}

Die ondersoekvrae wat in die Inleiding hierbo gestel is, is hiermee beantwoord. Die resultate van die ondersoek verskaf aan ons ' $n$ beeld van Aartsbiskop Desmond Tutu as 'n toegewyde pastor en 'n profetiese prediker met ' $n$ besonder helder verstaan van die essensie van die evangelie van Jesus Christus in die Suid-Afrikaanse konteks.

\section{NOTAS:}

1 H J C Pieterse (ed), Desmond Tutu's message. A qualitative analysis, Kampen/Weinheim 1995.

2 J P Groenewald, Maatskaplike naworsing: ontwerp en ontledings, Pretoria 1981, 51 .

3 R G Burgess, In the field: an introduction to field research, London 1984, 55.

4 B G Glaser \& A L Strauss, The discovery of grounded theory, Chicago 1967.

5 Pieterse, $a w, 144$.

$6 \quad$ Pieterse, $a w, 13,38$.

7 Pieterse, a w, 116-138; vergelyk ook K D Bailey, Methods of social research, New York 1982; R C Bogdan \& S K Biklen, Qualitative research for education: an introduction to theory and methods, Boston 1982.

8 V Peters, F Wester \& R Richardson, Kwalitatieve analyze in de praktijk en handleiding bij Kwalitan versie 2, Nijmegen 1990.

$9 \quad$ Pieterse, $a w, 116-138$.

10 Pieterse, $a w, 145-152$.

11 Pieterse, $a w, 39$.

12 Pieterse, $a w, 45-48$. 
13 Pieterse, $a w, 49$.

14 Pieterse, $a w, 45-46$.

15 Vergelyk The Kairos Document, Braamfontein 1986, 17-18 waarin dieselfde begrip gebruik word.

16 Pieterse, $a w, 44$.

17 Pieterse, $a w, 50$.

$18 \quad$ Ibid.

19 Vergelyk E Henau, "De homilie als vorm van communicatie: grenzen en mogelijkheden", in: Liturgie en taal (geredigeer deur L Leijssen), Leuven 1992, 77-98.

20 R Zerfass, Grundkurs Predigt: Spruchpredigt, Düsseldorf 1987; R Zerfass, Grundkurs Predigt: Textpredigt, Düsseldorf 1992.

21 H J C Pieterse, Venwoording en prediking, Pretoria 1985 (Engelse uitgawe: Communicative preaching, Pretoria 11987, 21991, 31995); H J C Pieterse, Gemeente en prediking, Pretoria 1991.

22 E Henau, Inleiding tot de praktische homiletiek, Averbode 1976.

23 E Henau, a w 1992, 95-98.

24 Vergelyk Pieterse, Desmond Tutu's message, 1995, 63-72.

25 C Burbach, Argumentation in der politischen Predigt, Frankfurt 1990.

26 Pieterse, Desinond Tutu's message, 1995, 63-72.

27 Ibid.

28 Pieterse, $a w, 1995,64-65$.

29 Kyk vir 'n volledige verslag van die analises: Pieterse, Desmond Turu's message, 1995, 72-75. 